\title{
PENCIPTAAN TARI ANAK-ANAK DISABILITAS KAMI TAK BERBEDA
}

\author{
Jonet Sri Kuncoro ${ }^{1,}$ Eko Supendi ${ }^{2}$ \\ Jurusan Tari, Fakultas Seni Pertunjukan \\ Institut Seni Indonesia (ISI) Surakarta \\ 1Email: jonet@isi-ska.ac.id \\ 2Email: ekosupendi@isi-ska.ac.id
}

\begin{abstract}
The dance work entitled "Kami Tak Berbeda" (We Are Not Different) is a dance work specifically for children with disabilities. This work is a development of previous works made by Jonet Sri Kuncoro. In this work combines deaf children, the blind, and physically disabled. This work is supported by three extraordinary schools in Solo Raya, namely SLB Cangakan Karanganyar and SLB B-C Hamong Putro Sukoharjo. This work was created with the approach of developing a pattern of six arising dots cell consisting of three rows with two dots on Braille letters made of 4/4 measure and sign language for the deaf and poetry reading. The peak process of the practice is a dance performance that has a form of performance combining the development of Braille letters pattern with sign language in group choreography supported by musical accompaniment as a power to express the atmosphere.
\end{abstract}

Keywords: Disability, Deaf, Blind, Braille, Sign Language.

\section{Pendahuluan}

Karya tari hingga kini tidak familiar dengan orang-orang berkebutuhan khusus (disabilitas). Meskipun usaha-usaha untuk melakukan pelatihan tari banyak dilakukan di sekolah-sekolah luar biasa dan biasanya hanya untuk keperluan lomba. Anak-anak berkebutuhan khusus yang biasa melakukan pelatihan tari adalah tuna rungu. Mereka tidak bisa mendengar dan biasanya juga tidak bisa mengucap. Tetapi masih bisa menirukan setiap gerakan yang diajarkan.

Pengalaman pengkarya yang pernah membuat karya bagi anak-anak tuna rungu tingkat sekolah SD, SMP, dan SMA memperkuat alasan untuk kembali membuat karya yang berbeda. Pengkarya memiliki rencana untuk membuat karya tari bagi penyandang tuna netra sekaligus tuna rungu serta tuna daksa.

Pengkarya memiliki ide untuk membuat gerakan berdasarkan huruf-huruf yang ada pada tabel huruf Braille. Sebagai gerak dasar untuk gerakan tangan dan gerakan kaki. Untuk mempermudah latihan, pengkarya merubah system dari enam titik timbul tidak dalam hitungan satu sampai enam tetapi menjadi satu sampai empat. Cara hitungan sampai empat ini disamakan dengan hitungan pada latihan menari: satu, dua, tiga, empat dan hitungan birama 4/4. Hitungan ini nantinya juga akan mempermudah iringan tari untuk menyesuaikan gerakan tari.

Huruf-huruf Braille menggunakan kerangka penulisan seperti kartu domino. Satuan dasar dari sistem tulisan ini disebut sel Braille, di mana tiap sel terdiri dari enam titik timbul; tiga baris dengan dua titik. Keenam titik tersebut dapat disusun sedemikian rupa hingga menciptakan 64 macam kombinasi. Huruf Braille dibaca dari kiri ke kanan dan dapat melambangkan abjad, tanda baca, angka, tanda musik, simbol matematika dan lainnya. Ukuran huruf Braille yang umum digunakan adalah dengan tinggi sepanjang $0.5 \mathrm{~mm}$, serta spasi horizontal dan vertikal antartitik dalam sel 
sebesar $2.5 \mathrm{~mm}$ (https://id.wikipedia.org/wiki/ Braille).

Penciptaan karya tari ini berangkat dari ketukan irama dan huruf Braille yang dikombinasikan sedemikian rupa untuk mempermudah cara bermain. Demikian pula pada anak-anak tuna rungu akan digunakan metode pelatihan yang berbasis pada bahasa isyarat yang telah dikuasainya.

Setelah melatih anak-anak di SLB Negeri Cangakan, Karanganyar, kemudian pengkarya mencoba akan menerapkan metode kepelatihan ini di sekolah yang berbeda yaitu, SLB B-C Hamong Putro, Sukoharjo.

Bagi pengkarya, proses pembuatan karya ini bukanlah ingin membuat karya tari yang "beneran" tetapi sebuah wadah bermain bagi anak-anak. Bermain-main dalam gerakan-gerakan yang sebenarnya dilakukan dalam kegiatan keseharian. Sebuah gerakan yang kemudian ditata dan diatur sesuai irama hitungan satu, dua, tiga, sampai delapan.

Judul dari karya tari ini adalah "Kami Tak Berbeda". Dalam karya ini pengkarya berharap bahwa anak-anak yang memiliki berbagai hambatan ini dapat pula melakukan hal-hal yang sama dengan anak-anak normal lainnya, termasuk belajar tari. Kami tak berbeda diharapkan dapat mendorong pengkarya dan anak-anak untuk berlatih lebih semangat agar dapat berekspresi seperti anak-anak seumurnya yang normal.

Karya ini lahir dari hasil eksplorasi terus menerus bersama anak-anak difabel yang dimulai dari anak-anak berhambatan pendengaran menghasilkan karya "Aku Bisa". Kemudian bersama anak-anak berhambatan penglihatan menghasilkan karya "Braille Tubuh". Pengkarya kemudian melakukan proses dan eksplorasi untuk menggabungkan anakanak berhambatan pendengaran dan penglihatan sehingga lahirnya karya "Kami Tak Berbeda" ini.

Harapan pengkarya dalam project ini sangat sederhana, dengan permainan gerak anak-anak mampu berekspresi sesuai dengan kemampuan masing-masing. Pengkarya tidak ingin menjadikan mereka menjadi penari tetapi memberi kesempatan kepada mereka merasakan pentas tari dan ditonton banyak orang. Dengan karya ini semoga anak-anak tumbuh kepercayaan diri dan merasa tidak berbeda dengan anak-anak lainnya yang normal.

Metode yang digunakan pengkarya mencipta tari bagi anak-anak hambatan dengar dan wicara ini sangat sederhana. Pengkarya menyuruh anak-anak untuk melakukan gerakan keseharian, mulai bangun tidur, pergi ke sekolah, kegiatan di kelas, sampai aktivitas di rumah. Kemudian pengkarya juga menyuruh anak-anak melihat video tentang tari atau gerakan-gerakan yang disukainya. Pada saat latihan gerakangerakan itu dipresentasikan masing-masing anak.

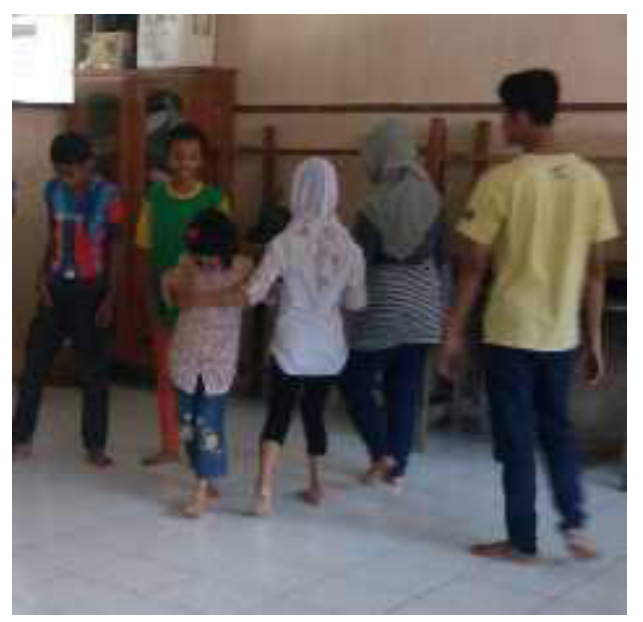

Gambar 2: Latihan gerakan keseharian.

Foto : Dokumentasi Jonet Sri Kuncoro

\section{Berlatih Bersama Anak-anak Tuna Netra}

Pada akhir tahun 2017, pengkarya merasa rindu dengan anak-anak SLB untuk melatih tari lagi. Inisiatif ini murni dari pengkarya karena ada tanda tanya dalam diri sendiri, bagaimana kalau yang menari adalah anak-anak yang memiliki hambatan penglihatan? Kegelisahan ini yang kemudian membawa pengkarya untuk kembali menyambangi SLB Negeri Cangakan, Karanganyar.

Hasil dari observasi di lapangan memperlihatkan kenyataan terhadap kondisi 
sesungguhnya bahwa anak-anak tuna netra takut bergerak, minder, dan tidak percaya diri. Kondisi ini menimbulkan pertanyaan pengkarya bagaimana mau di ajak menari?

Kenyataannya anak-anak tersebut mengangkat tangan agak tinggi saja takut, apalagi mengangkat kaki. Anak-anak takut akan keseimbangan diri, tidak percaya diri, dan mudah sekali tersinggung. Anak-anak ini hanya mengandalkan naluri dan indera pendengaran sehingga wajar mereka tidak percaya kepada orang yang baru saja dikenalnya.

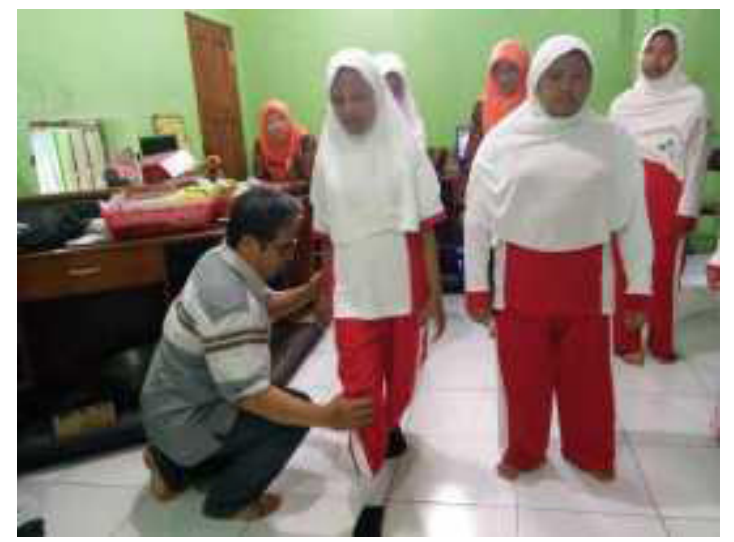

Gambar 4: Untuk melakukan setiap gerakan, baik itu tangan atau kaki harus selalu dibimbing, yaitu dengan cara dipegang terus diarahkan

Foto: dok. Jonet Sri Kuncoro.

Pengkarya memulai dengan belajar dan bermain bersama anak-anak sambil mengamati cara belajar dan aktivitas keseharian mereka. Salah satu yang diamati pengkarya adalah bagaimana cara mereka berkomunikasi lewat handphone (HP). Susunan huruf yang menjadi kata dari keyboard HP dapat diterima menjadi suara.

Mengenal dengan baik setiap pribadi menjadi kunci utama dalam pendekatan komunikasi. Ketika komunikasi dengan anakanak lancar, kita dapat berbaur lewat permainanpermainan dan aktivitas keseharian mereka, termasuk cara baca tulis mereka. Terus terang pengkarya merasa asing terhadap metode mereka membaca atau menulis.

Berawal dari melihat anak menulis huruf
Braille pengkarya tertarik untuk melihat dan bagaimana kerja symbol titik-titik dalam Braille tersebut menjadi susunan huruf dan kata. Dari sinilah muncul niatan pengkarya untuk belajar huruf Braille lebih intensif. Dalam penulisan hurufBraille ada patokan setiap huruf terdiri dari enam titik. Tiga ke bawah dan dua ke samping kanan.

Kondisi anak-anak yang takut mengangkat tangan dan kakiuntuk menggerakkan ke arah yang lebih luas. Pengkarya memiliki gagasan mengajarkan gerakan-gerakan kaki dengan menghentak-hentakkan ke lantai supaya berbunyi. Yang disesuaikan dengan titik-titik timbul Braille yang di modifikasi sebagai gerak dasar untuk gerakan tangan dan gerakan kaki.

Pengkarya dalam memudahkan proses latihan menggunakan hitungan birama 4/4 sebagai irama atau tempo setiap gerakan. Penggunakan tempo birama 4/4 ini diharapkan akan memudahkan hitungan gerak dan hitungan pada iringan musiknya. Sehingga anak-anak tuna rungu akan mudah menghafalkan setiap gerak dan perubahannya.

3. Menggabungkan Pelatihan Anak-anak Tuna Rungu dan Tuna NetraPengkarya dalam rancangan garapan karya $\mathrm{K}$ a $\mathrm{m} \mathrm{i} \quad \mathrm{T} \mathrm{a} \mathrm{k}$ Berbeda ini mencoba membuat alternatif komposisi titik. Komposisi titik dalam Braille terdiri dari enam titik, dua lajur dan 3 baris. Pengkarya membuat gerakan berdasar abjad pada huruf Braille. Dengan menggunakan hitungan satu sampai delapan dengan birama 4/4. Dalam pelaksanaannya titik yang ditusuk sebelah kiri untuk tepuk tangan sedangkan titik yang ditusuk di sebelah kanan hentakan kaki. Karena anak yang memiliki keterbatasan daya penglihatan ini untuk menggerakan dua anggota tubuh (tangan dan kaki) bersamaan sangat takut dan terlalu lama memikirkan tentang perintah itu. 


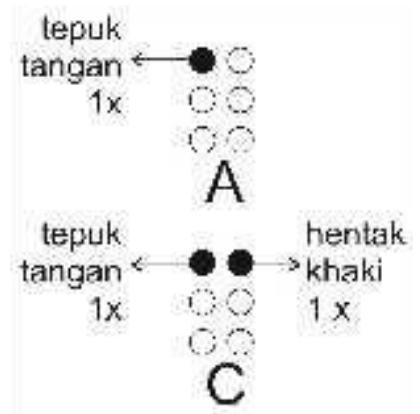

Gambar 6: Contoh huruf dalam gerakan tepuk dan hentak

Dari uraian di atas pengkarya mencoba mengenalkan huruf Braille dengan gerak. Diharapkan anak berani bergerak dengan kedua anggota tubuh bersamaan. Proses berikutnya adalah mengabungkan latihan anak-anak tuna netra dengan anak-anak tuna rungu. Anak-anak tuna rungu menggunakan gerak tangan dan kaki yang sama, tetapi karena mereka memiliki daya lihat, untuk pola lantai lebih variatif dan mengisi ruang dalam pola-pola tertentu.

Pada saat latihan di SLB Negeri Cangakan bersama anak-anak tuna rungu dan tuna netra datanglah seorang anak perempuan berkursi roda, satu sekolah dengan mereka. Melihat teman-temannya menari anak itu ingin ikut. Pengkarya agak bingung bagaimana memasukkan materi kursi roda dalam garapannya. Pengkarya kemudian bertanya selain pengin menari apa yang dia bisa. Si anak tersebut menjawab menulis puisi dan sekaligus pengkarya menyuruhnya membaca puisi tersebut.

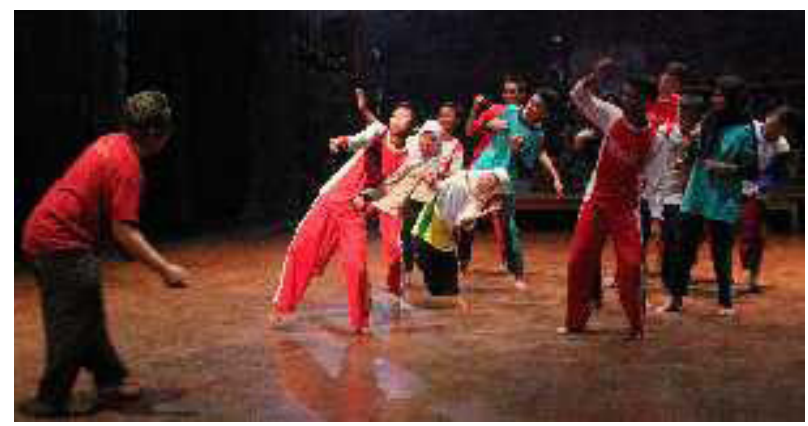

Gambar 7: Latihan Bersama

Foto : Dokumentasi Jonet Sri Kuncoro

\section{Pembahasan}

\section{A. Proses Penciptaan Karya}

Proses penciptaan karya ini di awali dari pengenalan, melihat kemampuan yang di miliki, merangkai gerak, penggabungan, dan finishing.

1. Pengenalan

Pengkarya merasa bahwa anak-anak perlu dikenalkan gerak terlebih dahalu. Pengenalan gerak untuk anak-anak tuna netra dilakukan di dalam kelas. Untuk anak-anak tuna rungu karena ada beberapa yang pernah ikut menari melihat beberapa video tari.

2. Melihat kemampuan yang di miliki. Anak-anak tuna rungu diberi kebebasan bergerak sesuai dengan pengalaman pribadinya. Mereka bergerak sesuka hati sesuai pengalaman masing-masing. Untuk anak-anak tuna netra melatih keberanian bergerak dan memberitahu fungsi anggota tubuh untuk bergerak. Terutama keberanian menggunakan kaki dan tangannya secara bebas.

\section{Merangkai Gerak}

Anak-anak tuna rungu gerak yang di rangkai adalah gerakan hasil eksplorasi anak-anak terhadap gerak keseharian dan kemampuan gerak hasil tiruan pada gambar di video. Dari sinilah kemudian pengkarya memilih gerak-gerak yang disesuaikan dengan iringan dan kemudian merakitnya dengan gerak-gerak transisi.

\section{Penggabungan}

Menggabungkan gerak-gerak anak-anak tuna rungu dan anak-anak tuna netra sesuai dengan pola lantai dan penyesuaian dengan music. 


\section{B. Deskripsi Karya}

a. Judul dan Sinopsis

Judul untuk karya tari ini adalah "Kami Tak berbeda" Sebuah doa dan pengharapan pengkarya bahwa anak-anak yang memiliki hambatan penglihatan dan pendengaran mampu melakukan kegiatan-kegiatan yang sama dilakukan oleh teman sebaya yang normal. Gerak-gerak yang dilakukan, adalah gerakan sederhana untuk membantu anak-anak melakukan latihan keseimbangan tubuh. Yaitu mengangkat tangan dan gerakan kaki. Dorongan dan semangat dari pengkarya dalam upaya anak-anak percaya diri bahwa menggerakkan anggota tubuh (tangan dan kaki) tidak membuat mereka terjatuh, bertabrakan dengan teman, atau kehilangan keseimbangan.

\section{Sinopsis}

Kami tak membuat karya tari. Pun, kami tak berlatih tari selayaknya saudara kami, Apalagi mengajarkan tari-tarian. Kami bertemu menjalin silaturahmi, Belajar berkomunikasi satu dengan yang lain. Kami hanya bermain, bergerak sesuai keseharian kami. Dan itulah kemampuan kami dirangkum dalam ilustrasi dan tembang. Suara lirih itu terucap "Kami Tak Berbeda".Inilah tarianku, tarian yang muncul dalam keriangan bermain dan silam dalam meraba kegelapan.

Babak I ; Semua muncul dari kanan kiri stage. Penari Tuna Rungu muncul dari kanan kiri stage bagian tengah. Penari Tuna Netra muncul dari kiri stage belakng dengan pendamping. Salah satu pendamping (P) menanyakan pada penari Tuna Rungu (TR). Suasana gembira. Iringan gender.

$$
\begin{array}{ll}
\text { Dialog : } & \\
\mathrm{P} & : \text { Kamu mau apa? } \\
\mathrm{TR} & : \text { (dijawab oleh semua penari) } \\
& \text { Mau menari! } \\
\mathrm{P} & : \text { Apa kamu bisa menari } \\
\mathrm{TR} & \vdots \text { Saya bisa menari } \\
\mathrm{P} & \vdots \text { Coba bapak mau melihat, siapa }
\end{array}
$$

yang berani mencoba (salah Satu penari (Diky) berani mencoba menari, setelah menari semua penari memberi tepuk tangan)

$\mathrm{P} \quad$ : Siapa lagi yang mau mencoba

TR : (Semua menjawab) Tidak, aku maunya bersama

P : Ya...sekarang menari bersama, bapak di depan memberi aba-aba kamu. Lihat bapak Ya

TR : Ya....уа...уа

Babak II, Penari berjajar dengan gerakan;salam "Selamat Pagi Semua (bahasa isyarat), Lihat Kami Menari. Kemudian gerakan entrakan dilakukan 3 x 8, Gedrugan dilakukan $3 \times 8$, langkah kaki maju mundur $3 \times 8$, dan Jengkeng hadap depan. Music ilustrasi dan genderan.

Babak III, Penari Tuna Netra berdiri satu persatu, tangan meraba, Hoyogan balik kanan hadap depan. Penari Tuna $\mathrm{N}$ e t $\mathrm{r}$ a bergerak (Pentangan asto), penari Tuna Rungu berdiri gerak bersaman dengan penari Tuna Netra (Pentangan tutup netra), penari Tuna Rungu berjalan membuka ke kanan dan kekiri sedang penari Tuna Netra berjalan ke depan $16 \mathrm{x}$. Gerak bersama (gerak ukelan asto kanan kiri), pentang kedua tangan silang, jengkeng 3 x. music: Pathetan, Kemanak, Mijil Dempel. Susana sedih.

Babak IV, berdiri dua penari Tuna Rungu membacakan Puisi; Inilah Aku, Lihatlah Aku menari, Aku bisa. Music: gender. Suasana semangat.

Babak V, Penari Tuna Rungu berdiri dilanjutkan menari bersama, mulai dari gerakan salam, Pentangan kanan kiri, Glebagan mentang asto, Leyekan badan mentang asto, Ukelan asto kiri, Ukelan asto kanan. Penari Tuna Rungu berjalan kebelakang $(2 \times 8)$, gerak hoyogan badan $(2 \times 8)$ dan penari Tuna Netra entrakan kaki $(2 \times 8)$, gerak kaki maju mundur $(2 \times 8)$ 
dilanjutkan gerakan membuat abjad. Music lancaran. Suasana ceria.

Babak VI, Semua menari bersama; Gerakan Pentangan kanan kiri, Gerakan Garuda, diakhiri kepal tangan kanan di depan dada, Penari Tuna Neta dan Tuna Daksa ngomong kami tak berbeda sedangkan penari Tuna Rungu memakai bahasa isyarat diakhiri dengan pose bebas. Music ilustrasi. Suasana ceria.

Bentuk pertunjukan karya tari Kami Tak Berbeda ini adalah tari berkelompok yang melibatkan anak-anak tuna netra berjumlah 5 anak, tuna rungu berjumlah 18 anak, dan seorang anak tuna daksa. Secara keseluruhan penataan tari di kelompokan dalam tiga bagian. Bagian pertama adalah penataan tari untuk anak-anak tuna rungu, kemudian penataan untuk anak-anak tuna netra, dan yang terakhir adalah penggabungan penataan tari untuk anak-anak tuna rungu dan tuna netra.

Ketiga bagian itu dikemas dalam wadah music elektronik yang digabungkan dengan gendhing-gendhing palaran maupun pathetan yang disajikan langsung oleh beberapa instrument gamelan Jawa (Gender, Rebab, Kethuk-Kempul, bonang, Kemanak) dan satu vocal perempuan (swarawati). Music elektronik berfungsi sebagai alur untuk ketukan. Artinya, sebagai pengatur tempo gerakan sekaligus patokan hitungan pada setiap gerakan.

Gendhing-gendhing palaran maupun pathetan disajikan secara langsung dimaksudkan untuk mendukung suasana tertentu dalam garapan. Misalnya suasana nglangut, sedih, dan trenyuh. Penggunaan instrument gamelan ini digunakan pula saat adegan pembuka dan penutup pertunjukan.

Adegan karya tari Kami Tak Berbeda dibuka dengan munculnya dua anak tuna rungu dari kanan dan kiri panggung. Mereka akan bermain, kemudian mereka memanggil teman masing-masing dan muncul secara rombongan dari kanan dan kiri.

Adegan berikutnya adalah menari bersama yang dipandu oleh pengkarya dari depan di antara penonton. Pengkarya memandu para penari dari depan menggunakan bahasa isyarat. Kadang-kadang juga memberikan contoh gerakan kaki dan tangan.

Setelah anak-anak tuna rungu berhenti pada posisi jongkok, kemudian empat orang anak tuna netra mulai berdiri pada posisi di belakang tengah. Keempat anak tersebut menghadap belakang dengan menggerakan kedua tangan ke atas.

\section{Gerak}

Karya tari Kami Tak Berbeda menggunakan materi vokabuler gerak keseharian. Hal ini disebabkan karena mereka bukanlah penari atau anak-anak yang tidak terbiasa menari. Sejak awal pengkarya tidak bermaksud untuk melatih atau mengajari tarian kepada anak-anak. Intinya pengkarya tidak akan membuat mereka menjadi penari.

Pengkarya, ketika bertemu dengan anak-anak menyadari bahwa mereka tidak bisa dipaksa atau ditekan untuk belajar sesuatu, termasuk menari. Kondisi anak-anak yang merasakan hal yang kurang pada dirinya menjadi pribadi yang posesif dan cenderung sensitive. Mereka menjadi pribadi-pribadi yang sangat peka dan perasa.

Terutama anak-anak berhambatan penglihatan, mereka sangat tertutup, waspada, dan berhati-hati. Mereka hanya percaya kepada orang-orang dekat dan orang yang sudah sangat dikenalnya. Maka, dalam hal ini pengkarya sangat berhati-hati memperlakukan anak-anak.

Karya Kami Tak Berbeda, pengkarya mencoba memanfaatkan gerakan bahasa isyarat sebagai gerakan tarian. Mulai dari mengeja huruf-huruf abjad menjadi susunan kata kemudian kalimat. Sehingga bila dilihat secara cermat mereka bergerak dengan kata-kata yang tersusun kalimat. 


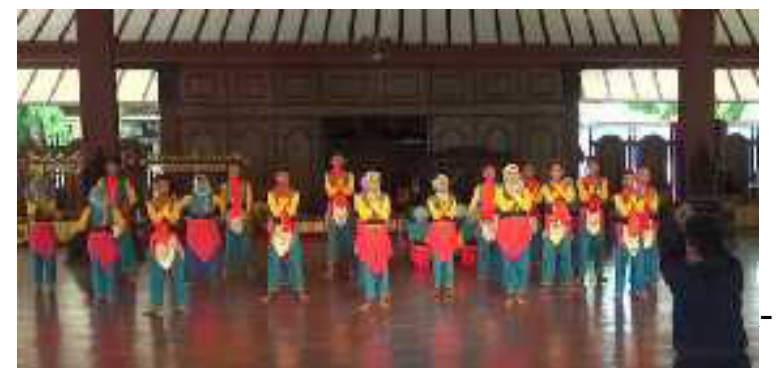

Foto : dokumentasi Jonet Sri Kuncoro.

Berbeda dengan anak-anak tuna rungu, anak-anak tuna netra cenderung lebih pasif untuk bergerak. Mereka selalu waspada dan berhati-hati sehingga untuk mengangkat tangan atau kaki saja takut. Pengkarya memperlakukan anak-anak tuna netra dalam melatih gerak dengan cara menyentuh. Misalnya, untuk mengangkat tangan kanan disentuh tangan kanan kemudian di dorongkan ke atas. Awalnya mereka takut tetapi lama-lama menjadi terbiasa baru kemudian di latih gerakannya. Demikian pula untuk latihan gerak kaki.

Karya Kami Tak Berbeda memiliki pola lantai yang sederhana. Terutama untuk anak-anak tuna netra karena terbatas pada pergerakan atau perpindahan. Anak-anak tuna netra muncul saat ramai rombongan muncul di tengah panggung. Mereka

memulai dari level rendah (duduk) menghadap ke belakang. Kemudian berdiri-masih menghadap belakang - mulai menggerakkan tangan ke samping dan ke atas. Setelah gerakan itu anak-anak berbalik badan bergerak kemudian menuju depan.

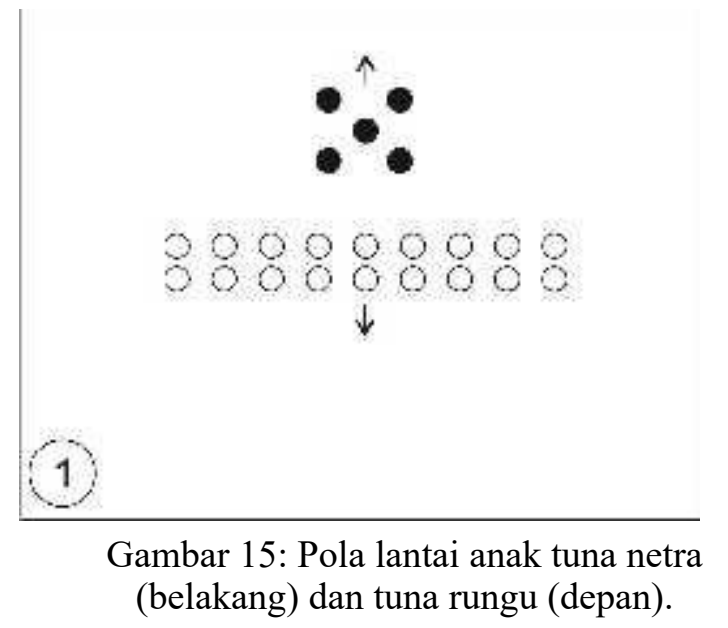

Adegan setelah dialog antara anak-anak dan pengkarya, pola lantai anak-anak tuna rungu berada di depan dan anak-anak tuna netra berada di belakang. Sehingga posisi anak-anak tuna netra (posisi level rendah) belum kelihatan. Hal ini dimaksudkan untuk memberi efek keterkejutan bahwa tiba-tiba anak-anak tuna netra muncul dari tengah panggung.

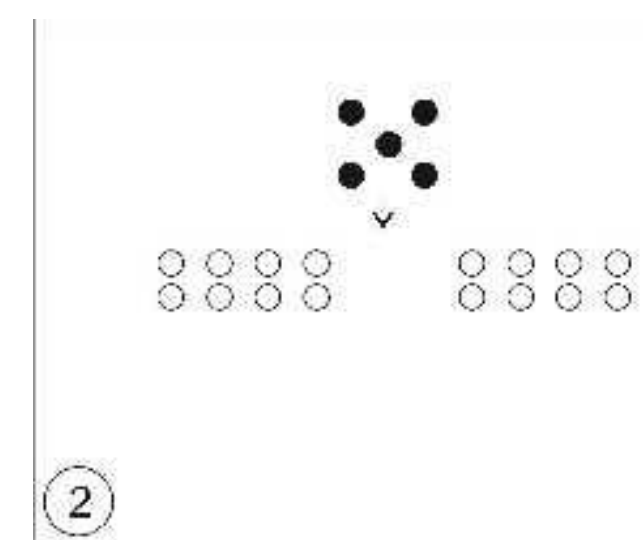

Gambar 16: Pola lantai kedua ini menunjukan setelah anak-anak tuna rungu menari kemudian terbelah menjadi dua bagian yang bergerak kenan dank e kiri sehingga anak-anak tuna netra kelihatan.

Setelah itu anak-anak tuna netra bergerak maju ke depan di antara anak-anak tuna rungu. Kemudian anak-anak tuna rungu mundur ke belakang memberi kesempatan anak-anak tuna rungu menampilkan gerakannya. Pada saat di belakang anak-anak tuna rungu masih tetap bergerak sesuai dengan pola-pola yang sudah di tentukan.

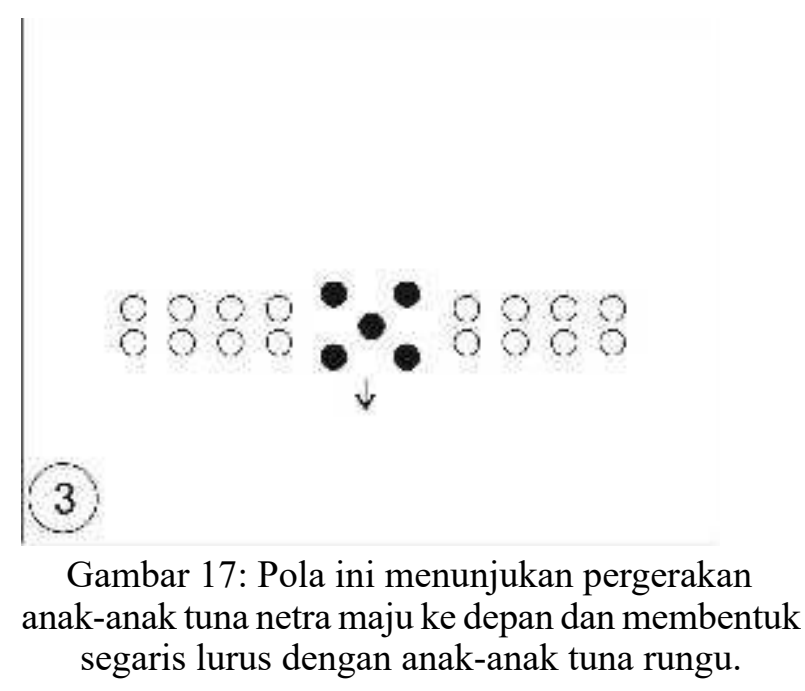




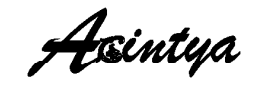

Jurnal Penelitian Seni Budaya

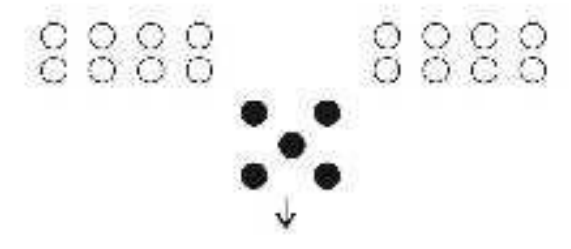

4

Gambar 18: Pola lantai pada saat anak-anak tuna rungu bergerak ke belakang.

\section{$8889 \cdot 9888$}

\section{(5)}

Gambar 19: Pada adegan ini pola lantai anak-anak tuna rungu dan tuna netra segaris. Sedangkan di depan anak tuna daksa membaca puisi.

Tema dalam garapan karya tari ini adalah kesetaraan. Sebuah keinginan anakanak disablitas untuk dapat merasakan pentas tari di atas panggung seperti halnya anakanak sebayanya yang normal. Secara kualitas barangkali tidak dapat disandingkan secara hasil kualitas gerak tetapi semangat dan kemauan untuk melakukan proses latihan patut di banggakan.

Seorang anak tuna daksa bernama Vansa Miktakhul Khasanah, kelas 9 SLB Negeri Cangakan menulis sebuah puisi. Puisi tersebut berjudul Kami Tak Berbeda. Puisi ini mencoba berkeluh kesah kepada Tuhan mengapai kami berbeda? Walaupun secara sadar bahwa anakanak tersebut berbeda dengan anak normal. Di akhir puisinya Vansa berharap bahwa Tuhan memiliki rencana yang indah bagi kaum disabilitas dan berharap mereka tak berbeda.
Sebagai intro untuk karya ini adalah pathetan. Pathetan ini merupakan ilustrasi suasana kegelisahan anak-anak disablitas untuk dapat menari bersama. Kemudian masuk ilustrasi music ketukan dari music elektro. Ketukan ini memberi tanda hitungan, ritme, dan suasana kegembiraan.

Bagian kedua terdengar ilustrasi tembang pathetan sendhon Abimanyu Laras Slendro Pathet Sanga. Lagu ini memberikan ilustrasi suasana hati untuk anak-anak tuna netra yang mengangkat semangat anak-anak untuk bertekat bisa melakukan sesuatu. Kemudian dilanjutkan dengan tembang Ketawang Mijil Lagu Dhempel Laras Slendro Pathet Sanga. Tembang ini berkisah tentang kebersamaan mewujudkan kesetaraan.

Rias adalah salah satu pendukung dalam pertunjukan karya tari Kami Tak Berbeda ini. Rias yang digunakan adalah rias natural yang menyesuaikan karakter anak-anak yang polos. Untuk anak-anak perempuan semua menggunakan hijab sedangkan untuk anaklaki-laki rambutnya beri hairspay warna cerah. Alat dan bahannya yaitu, pencil alis, sisir, saput bedak, kuas eye shadow, kuas lipstick, bedak tabur, bedak foundation, ross, lipstick, eye shadow warna coklat.

Busana yang dipakai anak-anak perempuan mengambil warna cerah dengan bahan menggunakan kain satin, kaos lengan panjang warna kuning, celana panjang warna biru, rompi warna biru, berhijab warna merah muda, ikat pinggang warna hitam. Untuk busana anak laki-laki menggunakan celana panjang warna biru, kain warna putuh, ikat pinggang, warna hitam, kaos panjang warna kuning, dasi warna merah, rompi warna biru.

Dipilihnya tempat di pendapa ini mempertimbangkan tentang bentuk ruang yang semi terbuka dengan alasan bahwa anak-anak masih terbiasa dengan atmosfer keseharian. Tempat yang luas akan membuat suasana hati lega, terutama anak-anak dapat menghirup udara secara langsung dan bebas tanpa halangan dinding. Akan berbeda bila di tempatkan pada 
gedung tertutup Teater besar atau Teater Kecil yang cenderung hening yang gelap dan terkesan sempit.

Pemilihan tempat ini juga memiliki kekurangan yaitu masalah level panggung yang ada ketinggian. Anak-anak tuna netra harus ada yang memandu termasuk seorang anak yang menggunakan kursi roda. Namun, pengkarya meminimalisir garapan yang memungkin anakanak harus naik turun atau muncul-silam ke area panggung. Bahkan dalam garapan ini semua muncul satu kali saat pentas dan setelah selesai baru silam.

\section{Simpulan}

Karya tari Kami Tak Berbeda bagi pengkarya merupakan keinginan untuk kembali melakukan proses kreatif bersama anak-anak disabilitas. Pengalaman yang dikuasai pengkarya memantik proses kreatif untuk membuat karya tari yang menggabungkan anak-anak tuna rungu dan tuna netra sekaligus. Awalnya Nampak kesulitan karena kedua anak-anak ini memiliki karakter yang berbeda, sehingga latihan, awalnya dilakukan secara terpisah antara anakanak tuna rungu dan tuna netra.

Kebaruan yang ingin dicapai oleh pengkarya dalam karya Kami Tak Berbeda adalah menggabungkan metode pelatihan yang digunakan untuk anak-anak tuna rungu dan tuna netra. Penggunaan bahasa isyarat dan huruf braille juga dilakukan pada karya ini yang kemudian ditambah dengan mengambil sampel teknik tepukan dan gerakan kaki pada karya Stom Army.

Luaran yang ingin dicapai dalam penelitian ini adalah naskah ilmiah yang mengikuti panduan penelitian yang telah di tetapkan oleh Pusat Penelitian ISI Surakarta. Kemudian karya seni yang telah tercipta ini akan didaftarkan pada Hak Kekayaan Intelektual.

\section{Kepustakaan}

Asrorul Mais, Media Pembelajaran Anak Berkebutuhan Khusus. Jember: Pustaka Abadi. 2016

Asep As Hidayat dan Afe Suwandi, 2013, Pendidikan Anak Berkebutuhan khusus Tuna Netra, Jakarta: Luxima.

Mohammad Effendi, 2008, Pengantar Psikologi Anak Berkelainan, Jakarta: Bumi Aksara. 